\title{
Питання психології
}

УДК 159.923.5:35.08

DOI: $10.33099 / 2617-6858-21-59-1-5-11$

Андрусишин Ю. І. кандидат психологічних наук,

Начіональна академія Служби безпеки Украӥни

https://orcid.org/0000-0002-2948-6839

Радкович I. М. кандидат психологічних наук,

Служба безпеки Украйни

\section{ПСИХОЛОГІЧНІ ХАРАКТЕРИСТИКИ ВІЙСЬКОВОСЛУЖБОВЦІВ, НЕОБХІДНІ ДЛЯ ЇХНЬОЇ ВЛУЧНОЇ СТРІЛЬБИ}

У статті окреслено необхідність наявності у військовослужбовиів комплексу психологічних характеристик як передумови здійснення ними влучної стрільби. Визначено групи особистісних характеристик та обтрунтовано ӥхню значущість у прочесі формування навичок ведення причільної стрільби із вогнепальної зброї задля вдосконалення стрілещької майстерності. Окреслено доиільність розвитку інтелектуальних, мотиваційних та емоџійно-вольових якостей, а також урахування психофізіологічних особливостей задля підвищення ефективності оволодіння теоретичними знаннями й практичними навичками виконання влучного пострілу. Підкреслено, що наявність зазначених характеристик дасть змогу військовослужбовиям успішно долати негативні психічні стани та основні труднощі, що можуть виникати під час стрільби; активізувати психічні процеси $i$ мобілізувати можсливості організму задля влучення у иџіль; покращити здатність конщентруватися на завданні та уміння швидко приймати оптимальні рішення з метою ефективного застосування зброї в екстремальних умовах професійної діяльності.

Ключові слова: психологічні характеристики; військовослужбовиі; влучна стрільба; застосування вогнепальної зброї; екстремальні умови.

Вступ.

Виконання професійних завдань військовослужбовцями передбачає застосування вогнепальної зброї, зокрема у непередбачуваних екстремальних ситуаціях. Стрільба у таких напружених умовах вимагає урахування впливу стресогенних факторів на психіку військовослужбовців. У процесі застосування вогнепальної зброї при вирішенні ними професійних завдань важливу роль відіграє психологічна складова, а влучність стрільби, при цьому, забезпечується комплексом розвинених психологічних характеристик.

Відтак, метою статті $є$ виокремлення комплексу психологічних характеристик військовослужбовців як передумови здійснення ними влучної стрільби.

\section{Теоретичне підгрунтя.}

Вивченням актуальних питань стрільби 3 вогнепальної зброї у межах здійснення професійної діяльності в екстремальних умовах займались I.О. Атаманенко, О.І. Біленко, В.В. Біліченко, О.В. Майстренко, I.В. Мартинов, B.I. Тробюк та ін. Водночас, психологічним аспектам навчання стрільбі військовослужбовців присвятили свої роботи О.Ю. Богуш, В.П. Дворецький, B.I. Малічевський, В.М. Монастирський та ін. Різноманітні проблеми формування й розвитку психологічних характеристик зазначеної категорії фахівців вивчали такі науковці, як: Н.Г. Іванова, О.В. Каверін, О.М. Керницький, Л.О. Матохнюк, В.А. Молотай, С.А. Мул, I.М. Окуленко, В.I. Осьодло, Н.Є. Пенькова, Н.А. Сторожук, О.В. Хуртенко та ін.

Водночас, І.Ю. Горелов та М.О. Чміль займались безпосередньо дослідженням психологічних характеристик особистості в аспекті застосування вогнепальної зброї в умовах впливу стрес-факторів. Зокрема, особливу увагу зазначені науковці акцентують на таких характеристиках, як [4; 11]: стресостійкість; наполегливість у досягненні мети; здатність до саморегуляції поведінки; адекватна самооцінка; швидкість у прийнятті рішень; вміння правильно оцінювати ситуацію; винахідливість і швидкість орієнтування; прогностичні навички тощо.

Окреслені наукові напрацювання $\epsilon$ основою для вивчення шляхів удосконалення комплексу психологічних характеристик військовослужбовців в аспекті оптимізації застосування ними вогнепальної зброї при виконанні професійних завдань.

Методи дослідження.

У процесі дослідження застосовувався метод аналізу наукової літератури та 


\section{Питання психології}

узагальнення сучасних підходів до дослідження питань розвитку психологічних характеристик військовослужбовців, необхідних для здійснення влучної стрільби. Також окреслена проблематика вивчалась 3 позиції діяльнісного та системного підходів. Останні дають змогу проаналізувати комплекс особистісних характеристик 3 урахуванням умов професійної діяльності, зокрема: обгрунтувати залежність влучної стрільби від комплексу когнітивних, емоційно-вольових, мотиваційних та психофізіологічних характеристик, спрогнозувати динаміку розвитку останніх, визначити їх вплив на результативність стрільби, на основі чого обрати найбільш ефективні оптимізаційні стратегії удосконалення комплексу психологічних характеристик військових фахівців, що $\epsilon$ важливою передумовою забезпечення успішного застосування вогнепальної зброї у процесі виконання професійних завдань.

\section{Результати і обговорення.}

Специфіка

військовослужбовцями

застосування табельної зброї матсимального використання -..1і бойови можливостей визначасться тим, цо поряд необхідністю засвойти значний обсяг теоретичних знань, правильно виконувати усі елементи пострілу, потрібно ще й володіти здатністю витримувати значні фізичні навантаження та психічну напруженість. Такі умови актуалізують значущість психологічних аспектів $\mathrm{y}$ процесі стрільби та залежність іï успішності від розвиненості психологічних характеристик особистості військовослужбовця. Останні сприятимуть гарантованому, а не випадковому влученню у ціль, ефективному формуванню навичок ведення прицільної стрільби із вогнепальної зброї, забезпечуватимуть вдосконалення стрілецької майстерності.

Так, при виконанні професійних завдань під негативним впливом стресфакторів поведінка військовослужбовців та результати їхньої стрільби значною мірою визначаються наявністю таких психологічних характеристик:

- здатності мобілізуватися та концентруватися на завданні, легко і швидко пристосовуватись до нових умов, підготовленості до дій в екстремальних ситуаціях;
- уміння керувати своїм емоційним станом під час виконання пострілу, емоційно-вольової стійкості, відповідальності, рішучості, самовладання, самокритичності, наполегливості, впевненості у своїх стрілецьких навичках;

- здатності адекватно оцінити ситуацію та прогнозувати іi результат, передбачати наслідки власних дій, приймати оптимальне рішення на відкриття вогню в умовах дефіциту часу тощо.

Загальновідомо, що саме розвинені інтелектуальні здібності забезпечують здатність військовослужбовців в умовах впливу стресогенних чинників знайти найбільш ефективні шляхи вирішення певної проблеми. До того ж, науковці наголошують на тому, що невідповідність інтелектуальних характеристик фахівців вимогам діяльності $€$ одним 3 важливих факторів ризику, що зумовлює виникнення психічної дезадаптації [9, 105].

За таких умов інтелект набуває особливого значення, оскільки 3 його допомогою військовослужбовці здатні осмислити стрес-фактори, що спричиняють виникнення деструктивних емоційних станів при стрільбі. Розвинені інтелектуальні здібності також дають змогу адекватно сприймати та оптимально реагувати у ситуаціях можливого застосування вогнепальної зброї. Відтак, успішність стрільби, зокрема швидкісної, обумовлюється динамікою таких пізнавальних процесів: цілісності й вибірковості сприйняття, переключення й концентрації уваги, критичності й гнучкості мислення, обсягу зорової пам'яті тощо.

Влучність стрільби при виконанні професійних завдань із застосуванням вогнепальної зброї визначається також наявністю у зазначеної категорії фахівців стійкої мотивації, зокрема глибокого інтересу до самовиховання й самовдосконалення у процесі оволодіння стрілецьких навичок і стійкого прагнення до досягнення позитивних результатів при стрільбі. Адже саме мотивація здійснює вплив на процес удосконалення професійних знань, вмінь, набуття необхідних навичок та розвиток відповідних якостей [5]. До того ж, мотивація є однією 3 важливих складових психологічної готовності військовослужбовців до професійної діяльності, що формує 


\section{Питання психології}

спрямованість - системоутворювальну властивість, у якій виражаються цілі, мотиви i суб'єктивне ставлення особистості до різних сторін діяльності [2; 10].

Мотивація досягнення передбачає прагнення до поліпшення результатів, наполегливість у досягненні своїх цілей, навіть ціною значних зусиль. При цьому, за умови розвиненої мотивації до успіху сподівання особи на позитивний результат зазвичай скромніші, ніж при слабкій мотивації досягнення. Загалом науковці [8] виокремлюють три принципових мотиваційних вектори, які першочергово визначають характер взаємозалежності діяльнісної активності і мотивації досягнення, зокрема:

\section{- індивідуальні}

суб' єктивні

уявлення про ймовірність особистісного успіху і складності завдання, що стоїть перед особою;

- $\quad$ ступінь значущості цього завдання для особи i, відповідно, прагнення підтримати і підвищити самооцінку;

- схильність конкретної особи до адекватного приписування собі самій, іншим людям і обставинам відповідальності за успіх і невдачу.

3 точки зору Д. Мак-Клелланда [8], мотивація досягнення може розвиватися i y зрілому віці, в першу чергу за рахунок навчання, а також у контексті професійної діяльності, коли людина безпосередньо відчуває усі переваги, пов'язані 3 відповідними досягненнями.

Тобто, стійка мотивація до досягнення успіху у процесі виконання влучного пострілу сприятиме успішності вогневої підготовки військовослужбовців та покрашенню ефективності застосування ними вогнепальної зброї при виконанні професійних завдань.

Необхідність розвитку емоційновольових характеристик для забезпечення влучної стрільби підтверджується тим, що основні помилки, які можуть виникати у процесі реалізації професійних завдань із застосуванням зброї, пов'язані із виникненням інтенсивних емоцій або переживань [3; 6]. Останні, порушуючи динаміку протікання психічних процесів, здатні призводити до афективного стану, дезорганізації рухових функцій та послаблення контролю над ними.

Тобто, реакція особистості на вплив стресогенних

факторів

стрільби

зумовлюється тривалістю, глибиною i стійкістю емоційного реагування, рівнем тривожності тощо [7]. Відтак, на перший план виходять вольові якості (оскільки основною функцією волі $\epsilon$ регулятивна), розвиненість яких детермінується оволодінням навичками саморегуляції та релаксації, почуттям обов'язку й відповідальністю, самоконтролем тощо.

Саме тому, в аспекті успішного застосування вогнепальної зброї необхідним для військовослужбовців $€$ оволодіння навичками емоційно-вольової саморегуляції задля оптимізації психічного стану в умовах фізичного та психологічного навантаження, корегування рівня емоційного збудження, формування ситуативної психологічної готовності тощо. Зазначене досягається як засвоєнням певного алгоритму дій під час стрільби, так і оволодінням спеціальних технік дихання, методів м’язової релаксації, навичок рефлексії, що дадуть змогу зняти зайве напруження задля ефективного влучення у ціль.

Розвиток навичок емоційно-вольової саморегуляції сприятиме мобілізації психічних ресурсів військовослужбовців; регуляції їхніх психічних станів відповідно до завдань та цілей стрільби; підтриманню стабільного рівня активності, незважаючи на негативні відчуття чи переживання, що можуть виникати у процесі застосування вогнепальної зброї.

Важливість урахування у процесі стрільби психофізіологічних характеристик обумовлюється тим, що відсутність належної уваги до темпераменту може не лише перешкоджати успішному розвитку стрілецьких навичок, а й призвести до виникнення труднощів у процесі вогневої підготовки та подальшої професійної діяльності. Отже, влучність стрільби забезпечується також усвідомленням власних темпераментальних особливостей, які, як відомо, є відносно стійкими і мало змінюються під зовнішнім впливом.

При цьому, слід виходити із того, що переважання у військовослужбовців холеричного типу темпераменту визначає їх прагнення якнайкраще оволодіти усіма прийомами й правилами стрільбі та націленість на отримання конкретних результатів. Проте, їхні невдачі можуть супроводжуватись яскраво вираженими 


\section{Питання психології}

емоційними реакціями та зниженням мотивації. До того ж, таким фахівцям не притаманна здатність до виконання монотонних стрілецьких вправ і тривалої концентрації уваги на повторенні однієї і тієї ж дії. Зазначеним характеризуються i військові з переважанням сангвіністичного темпераменту. Останні також швидко втрачають інтерес до відпрацювання нових прийомів стрільби та розвитку стрілецьких навичок, можуть часто відволікатись, нехтувати необхідністю детального відпрацювання усіх елементів виконання пострілу i зосереджуватись лише на влученні у мішень.

\section{Флегматичність}

військовослужбовців

темпераменту врівноваженість та схильність до монотонного повторення одного елементу стрільби, допоки не буде досягнуто правильності його виконання. Також вони адекватно сприймають виникнення можливих помилок при стрільбі або невлучення у ціль. Не схильні до виражених емоційних реакцій, а тому під час відпрацювання стрілецьких вправ можуть не проявляти особливого ентузіазму. Військовим фахівцям 3 меланхолійним типом темпераменту притаманна замкненість у собі та емоційна нестабільність. Вони, як правило, концентруються на власних невдачах у стрільбі, легко піддаються впливу зовнішніх подразників, а також не здатні діяти в умовах обмеженого часу та за відсутності достатньої кількості інформації.

Урахування

зазначених психофізіологічних характеристик дасть змогу індивідуально відкорегувати методику, інтенсивність та тривалість тренувань, що сприятиме підтриманню концентрації уваги та підвищенню ефективності оволодіння як теоретичними знаннями, так i практичними навичками виконання влучного пострілу [1].

Тобто, влучність стрільби під час виконання професійних завдань із застосуванням вогнепальної зброї забезпечується наянвістю низки особистісних характеристик, а саме:

- інтелектуальних - здатність до швидкого переключення та розподілу уваги у процесі виконання пострілу, розвинена зорова пам'ять, володіння методикою стрільби;
- мотиваиійних - прагнення до удосконалення навичок стрільби та досягнення позитивного результату, усвідомлення важливості розвитку психологічних характеристик для забезпечення влучної стрільби;

- емоиійно-вольових - уміння диференціювати відчуття та здатність до рефлексії власних емоційних станів й поведінкових реакцій, розвинені вольові якості, навички саморегуляції;

- психофізіологічних - урахування особливостей різних типів темпераменту у процесі оволодіння стрілецькими навичками.

Загалом особистісних виокремленні групи характеристик військовослужбовців в аспекті здійснення прицільної стрільби інтегруються у:

- здатність до успішного використання знань 3 правил і прийомів стрільби, протидії негативному впливу стрес-факторів;

- впевненість у своїх силах, принциповість, емоційно-вольова стійкість, адекватна схильність до ризику;

- здатність до швидкого оцінювання ситуації, прогнозування можливих наслідків i оперативного прийняття рішення про доцільність застосування зброї;

- здатність адекватно діяти в ситуаціях можливого застосування зброї та контролювати власні емоції, хвилювання, роздратованість у процесі здійснення пострілу тощо.

Розвиток у військовослужбовців виокремлених психологічних характеристик у процесі оволодіння навичками влучної стрільби сприятиме:

активізації психічних процесів, задіяних у процес стрільби, актуалізації основних мотивів до здійснення влучного пострілу, успішному подоланню негативних психічних станів, що можуть зумовлювати неконтрольовану поведінку та невлучення у ціль;

подоланню успішній мобілізації можливостей організму задля влучення у ціль;

$\checkmark$ покращенню здатності концентруватися на завданні, уміння швидко приймати оптимальні рішення, успішно подолати перешкоди і впевнено діяти в екстремальних умовах професійної діяльності. 


\section{Питання психології}

\section{Висновки.}

Таким чином, узагальнення викладеного у публікації матеріалу дає змогу виокремити такі висновки:

- влучність

військовослужбовців наявністю комплексу розвинених психологічних характеристик, які дадуть змогу витримувати значні фізичні навантаження й психічну напруженість, а також сприятимуть гарантованому влученню у ціль i вдосконаленню стрілецької майстерності;

- для результативної стрільби у зазначеної категорії фахівців мають бути розвинені такі особистісні характеристики: інтелектуальні (цілісність й вибірковість сприйняття, переключення, концентрація й розподіл уваги, зорова пам'ять, критичність й гнучкість мислення), мотиваційні (інтерес до самовиховання й самовдосконалення у процесі оволодіння стрілецьких навичок, прагнення до досягнення позитивних результатів при стрільбі), емоційно-вольові (навички саморегуляції, здатність до рефлексії, уміння диференціювати власні відчуття, вольові якості); - влучність стрільби військовослужбовців визначається також усвідомленням власних темпераментальних особливостей, урахування яких дасть змогу індивідуально відкорегувати методику, інтенсивність та тривалість тренувань задля підвищення ефективності оволодіння теоретичними знаннями i практичними навичками виконання влучного пострілу;

- розвиток зазначених характеристик сприятиме: успішному подоланню негативних психічних станів та основних труднощів, що можуть виникати під час стрільби та зумовлювати неконтрольовану поведінку; активізації психічних процесів і мобілізації можливостей організму задля влучення у ціль; покращенню здатності концентруватися на завданні та уміння швидко приймати оптимальні рішення 3 метою конструктивної поведінки під час застосування зброї в екстремальних умовах професійної діяльності.

\section{Список використаних джерел}

1. Андрусишин Ю.І. Основні етапи розвитку психологічної готовності фахівців сектору безпеки до влучної стрільби / Ю.І. Андрусишин, В.Д. Чорноус // Психологічний часопис: наук. журнал. - Київ : Інститут психології імені Г.С. Костюка НАПН України, 2020. - Т. 6. Вип. 5 (37). C. 47-55.

2. Артюшенко О.Ф. Мотив досягнення та теоретичне обгрунтування його структурних компонентів / О.Ф. Артюшенко, Д.Л. Нечипоренко // Слобожанський науково-спортивний вісник. 2013. - № 5 (38). - С. 25-28.

3. Вайнштейн Л.М. Путь на Олимп. Глава: Психологическая подготовка стрелка-спортсмена [Электронный ресурс] / Л.М. Вайнштейн. - Москва, 2005. - 357 c. - URL : http://www. shootingua.com/books/book223.htm.

4. Горелов І.Ю. Психологічна готовність працівників ОВС до застосування вогнепальносилового впливу: автореф. дис. на здобуття наук. ступеня канд. психол. наук: спец. 19.00.09 «Психологія діяльності в особливих умовах» / І.Ю. Горелов ; Ун-т цив. захисту України. - Харків, 2008. - $19 \mathrm{c}$.

5. Іванова Н.Г. Структура та розвиток мотивації особистості до професійної діяльності / Н.Г. Іванова // Військова освіта : зб. наук. праць. - К., 2006. - № 2 (18). - С. 23-32.

6. Каримов А.А. Психические состояния стрелка во время службы / А.А. Каримов // Современные подходы к подготовке кадров внутренних дел и государственной противопожарной службы : материалы девятой межвуз. науч.-метод. конф. - Иркутск : ВСИ МВД России, 2004. - С. 246-248.

7. Конельська I.M. Теоретико-методологічні основи дослідження проблеми формування психологічної стійкості особистості / І.М. Конельська // Психологічні засади забезпечення службової діяльності працівників правоохоронних органів : матер. наук.-практ. конф. (м. Кривий Ріг, 31 березня 2017 р.). - Кривий Ріг, 2017. - С. 112-114.

8. Кручинин В.А. Формирование мотивации достижения успеха в подростковом возрасте : монография / В.А. Кручинин, Е.А. Булатова. - Н. Новгород: ННГАСУ, 2010. - 155 с.

9. Машук I.О. Формування психологічної готовності учнів спеціалізованих загальноосвітніх закладів міліції до навчально-службової діяльності в системі МВС України : дис. ... канд. психол. наук : спец. 19.00.06 «Юридична психологія» / І.О. Машук. - Київ, 2009. - 236 с.

10. Меліхова I.О. Мотивація досягнення успіху та індивідуальний стиль міжособистісної поведінки / І.О. Меліхова // Наукові студії із соціальної та політичної психології. - 2011. - Вип. 26. C. 224-230. 


\section{Питання психології}

11. Чміль М.О. Формування психологічної готовності працівників органів внутрішніх справ до застосування табельної вогнепальної зброї : автореф. дис. на здобуття наук. ступеня канд. психол. наук : спец. 19.00.06. «Юридична психологія» / М.О. Чміль. - Харків, 2007. - 24 с.

\section{References}

1. Andrusyshyn Yu. \& Chornous V. (2020) Osnovni etapy rozvytku psykhologichnoyi hotovnosti fahivtsiv sektoru bezpeky do vluchnoji strilby [The main stages of development of the security sector specialists' psychological readiness for precision shooting]. Psychological Journal, Vol. 6, Issue 5 (37), 47-55 (in Ukrainian).

2. Artyushenko O. \& Nechyporenko D. (2013) Motyv dosjahnennja ta teoretychne obgrunuvannja joho strukturnyh komponentiv [Motive to achieve and theoretical justification of its structural components]. Slobojan scientific sport journal, 5 (38), 25-28 (in Ukrainian).

3. Vajnshtein L. (2005) Put' na Olimp. Hlava: Psihologicheskaja podhotovka strelka-sportsmena [Way to Olymp. Chapter: Psychological training of shooter-sportsman]. Moscow, 357. Retreived from http://www. shooting-ua.com/books/book223.htm (in Russian).

4. Horelov I. (2008) Psyhologichna hotovnist' pratsivnykiv OVS do zastosuvannja vohnepal'nosylovoho vplyvu [Psychological readiness of internal affairs bodies' employees for fire and force impact application] (Abstract of $\mathrm{PhD}$ thesis). Kharkiv, 19 p. (in Ukrainian).

5. Ivanova N. (2006) Struktura ta rozvytok motyvatsiji osobystosti do profesijnoji dijalnosti [Structure and development of personality's motivation for professional activity]. Military education, 2 (18), 23-32 (in Ukrainian).

6. Karimov A. (2004) Psikhicheskije sostojanija strelka vo vremja clujby [Psychological states of shooter during the time of service]. Modern approaches to training of internal affairs and state fire service personnel: Proceedings of scientific practice conference. Irkutsk, 246-248 (in Russian).

7. Kornel's'ka I. (2017) Teoretyko-metodolohichni osnovy doslidgennja problemy formuvannja psykholohichnoji stijkosti osobystosti [Theoretical and methodological bases of research of the problem of personality's psychological resilience formation]. Psychological bases of support of law enforcement bodies personnel official activity: Proceedings of scientific practice conference. Kryvyj Rih, 112-114 (in Ukrainian).

8. Kruchinin V. (2010) Formirovanije motivatsiji dostijenija uspeha v podrostkovom vozraste [Motivation for success achievement formation in adolescentce] (Monograph). N. Novgorod, $155 \mathrm{p}$. (in Russian).

9. Mashuk I. (2009) Formuvannja psykholohichnoji hotovnosti uchniv spetsializovanykh zahal'noosvitnikh zakladiv militsiji do navchalno-slujbovoji dijalnosti v systemi MVS Ukrajiny [Formation of specialized police general educational institutions' pupils psychological readiness to educational service activity in the system of MIF of Ukraine] (PhD in Psychology thesis). Kyiv, 236 p. (in Ukrainian).

10. Melikhova I. (2011) Motyvatsija dosjahnennja uspikhu ta indyvidual'nyj styl' mijosobystisnoji povedinky [Motivation for success achievement and individual style of behavior]. Scientific studios in social and political psychology, 26, 224-230 (in Ukrainian).

11. Chmil' M. (2007) Formuvannja psykholohichnoji hotovnosti pratsivnykiv orhaniv vnutrishnikh sprav do zastosuvannja tabel'noji vohnepalnoji zbroji [Formation of psychological readiness of internal affairs bodies' employees for table firearms application] (Abstract of PhD thesis). Kharkiv, $24 \mathrm{p}$.

\section{Резюме}

Андрусишин Ю. И. кандидат психологических наук, Национальная академия Службы безопасности Украины Радкович И. М. кандидат психологических наук, Служба безопасности Украинь

\section{ПСИХОЛОГИЧЕСКИЕ ХАРАКТЕРИСТИКИ ВОЕННОСЛУЖАЩИХ, НЕОБХОДИМЫЕ} ДЛЯ ИХ МЕТКОЙ СТЕЛЬБЫ

В статье раскрыта необходимость наличия у военнослужащих комплекса психологических характеристик как предпосылки осуществления ими меткой стрельбы. Определены группь личностных характеристик и обоснована их значимость в процессе формирования навыков ведения прицельной стрельбы с огнестрельного оружия $c$ целью усовершенствования стрелкового мастерства. Очерчена челесообразность развития интеллектуальных, мотивачионных и эмочионально-волевых качеств, а также учета психофизиологических особенностей ради повыпения эффективности овладения теоретическими знаниями и практическими навыками осуществления меткого выстрела. Подчеркнуто, что наличие указанных характеристик даст возможность военнослужащим успешно одолевать негативные психические состояния и основные трудности, которые могут возникать во время стрельбы; активизировать психические процессы и мобилизовать возможности организма ради попадания в иель; улучшить способность 


\section{Питання психології}

концентрироваться на задании и умение быстро принимать оптимальные решения с иелью эффективного использования оружия в экстремальньх условиях профессиональной деятельности.

Ключевые слова: психологические характеристики; военнослужащие; меткая стрельба; использование огнестрельного оружия; экстремальные условия.

\section{Summary \\ Andrusyshyn Yulia PhD in Psychology, National Academy of the Security Service of Ukraine Radkovych Iryna PhD in Psychology, Security Service of Ukraine \\ PSYCHOLOGICAL CHARACTERISTICS OF SERVICEMEN, NECESSARY FOR ACCURATE SHOOTING}

Introduction. Shooting in stressful conditions requires taking into account the stressors impact on the servicemen's psyche. In the process of using firearms during professional tasks solving the psychological component plays an important role, and the accuracy of shooting is provided by a set of developed psychological characteristics.

Purpose. The purpose of the article is to single out a set of psychological characteristics of servicemen as a prerequisite for their accurate shooting.

Methods. The study was conducted using the method of analysis of scientific literature and generalization of modern approaches to the study of the development of servicemen's psychological characteristics, as well as taking into account the provisions of activity and systemic approaches.

Originality. Extreme conditions of professional activity of servicemen actualize the importance of psychological aspects in the process of firearms using and the dependence of shooting effectiveness on psychological characteristics of servicemen, which will promote guaranteed hitting the target, effective formation of target shooting skills.

Thus, shooting accuracy is determined by: the dynamics of cognitive processes (integrity and selectivity of perception, switching and concentration of attention, criticality and flexibility of thinking, the amount of visual memory); a stable motivation (deep interest in self-education and self-improvement during mastering shooting skills, a strong desire to achieve positive results in shooting); developed skills of emotional and volitional self-regulation (special breathing techniques, methods of muscle relaxation, reflection); taking into account psychophysiological characteristics (temperamental features that are relatively stable and change little under external influence). That is, effective shooting of servicemen is ensured by the presence of a number of personal characteristics, in particular: intellectual, motivational, emotional-volitional, psychophysiological.

Conclusion. The shooting accuracy of servicemen is ensured by the presence of a set of developed psychological characteristics, which will allow to withstand significant physical exertion and mental stress, as well as contribute to the guaranteed hitting of the target and improvement of shooting skills.

For effective shooting the following personal characteristics should be developed: intellectual, motivational, emotional-volitional.

The shooting accuracy is also determined by the awareness of temperamental features which will allow to individually adjust the method, intensity and duration of training in order to improve the effectiveness of theoretical knowledge and practical skills of accurate shooting.

The development of these characteristics will contribute to: the successful overcoming of negative mental states and the main difficulties that may arise during the shooting and cause uncontrolled behavior; activation of mental processes and mobilization of the body's ability to hit the target; improving the ability to concentrate on the task and to quickly make decisions in order to behave constructively when using firearms in extreme conditions of professional activity.

Key words: psychological characteristics; servicemen; accurate shooting; using of firearms; extreme conditions.

Автори заявляють про відсутність конфлікту інтересів.

Recelved/Поступила: 17.02. 21. 